\title{
Perspective
}

\section{Bat and virus}

\author{
Zhengli Shi (凶)
}

State key Laboratory of Virology, Wuhan Institute of Virology, Chinese Academy of Sciences, Wuhan 430071, China

$\bowtie$ Correspondence: zlshi@wh.iov.cn

Bat, the only flying mammal and count more than $20 \%$ of the extant mammals on earth, were recently identified as a natural reservoir of emerging and reemerging infectious pathogens. Astonishing amount (more than 70 ) and genetic diversity of viruses isolated from the bat have been identified in different populations throughout the world. Many studies focus on bat viruses that caused severe domestic and human diseases. However, many viruses were found in apparently healthy bats, suggesting that bats may have a specific immune system or antiviral activity against virus infections. Therefore, basic researches for bat immunology and virus-host interactions are important for understanding bat-derived infectious diseases.

Bats, originated about 50 million years ago, are currently widely distributed and make up more than $20 \%$ of extant mammals on earth (Simmons, 2005; Teeling et al., 2005). Bats are traditionally grouped into two suborders: Megachiroptera (Megabat), which contains a single family Pteropodidae (42 genera, including 166 species), and Microchiroptera (Microbat), which contains 16 bat families (135 genera, including 759 species) within the order Chiroptera (Simmons, 2005). Megabat mainly feed on fruit, and some bats, such as Pteropus, have long distance migration capability. Most microbats feed on insects, while some feed on birds, lizards, frogs, fish or blood (vampire bat) (Aguirre et al., 2003; Patterson et al., 2003). Bats have various habitats, including caves, trees, roof and discarded tunnels, with a large group from hundreds to thousands of individuals in the same habitat. Because of many unique biological properties such as echolocation, hibernation, flying ability and living environment, bats are considered as enigmatic mammals.

\section{BATS ARE NATURAL RESERVOIRS OF EMERGING AND REEMERGING HUMAN VIRUSES}

Bats as reservoirs of human viruses were recognized as early as 1920s when rabies was found in bat in South and Central
America (Sulkin and Allen, 1974), but bats as carriers of emerging zoonotic viruses were not well acknowledged until the mid-1990s. The number of identified bat viruses rapidly increased after the discovery of henipavirus and severe acute respiratory syndrome coronavirus (SARS-CoV). Up to today, more than 80 viruses, including members from families of Rhabdoviridae, Orthomyxoviridae, Paramyxoviridae, Coronaviridae, Togaviridae, Flaviviridae, Bunyaviridae, Reoviridae, Arenaviridae, Herpesviridae, Picornaviridae, Hepesviridae and Adenoviridae, have been isolated from different bat species (Calisher et al., 2006).

Rabies virus Since the discovery of bat borne rabies virus in 1920s, different genotypes of rabies or rabies-related viruses within the genus Lyssavirus of the family Rhabdoviridae have been documented in bats. There are seven recognized genotypes of lyssavirus (Bourhy et al., 1993): rabies virus (genotype 1), Lagos bat virus (genotype 2), Mokola virus (genotype 3), Duvenhage virus (genotype 4), European bat lyssavirus type 1 (EBLV-1; genotype 5), European bat lyssavirus type 2 (EBLV-2; genotype 6), and Australian bat lyssavirus (genotype 7). All the genotypes except Mokola virus have bat reservoirs (Badrane and Tordo, 2001). Human rabies caused by bat lyssavirus was incessantly reported in South and North America, Europe, Australia and Africa (Hanna et al., 2000; Favi et al., 2002; Badilla et al., 2003; Fooks et al., 2003; Nathwani et al., 2003; Paweska et al., 2006; Blanton et al., 2008; van Thiel et al., 2008).

Henipavirus The henipavirus is a new genus with the family Paramyxoviridae and contains only two closely related but distinct members, hendra virus ( $\mathrm{HeV}$ ) and nipah virus (NiV) (Eaton et al., 2007). Restricted only to Australia, HeV was initially described after an outbreak of severe respiratory disease in horses during September 1994, which ultimately results in deaths of 13 horses and 1 horse trainer in Hendra, Australia, a suburb of Brisbane (Murray et al., 1995). Since then, several sporadic outbreaks have been reported in Australia in 1999, 2004, 2006-2008 (Field, 2008). NiV was 
discovered in Malaysia during a major outbreak of acute respiratory syndrome in pigs occurring from September 1998 to June 1999, resulting in 265 cases of encephalitis in humans and 105 deaths (Chua et al., 2000). The similar disease outbreak has also been documented in Singaspore, India in 2001, Bangladesh in 2001-2008 (Paton et al., 1999; Chadha et al., 2006; Eaton et al., 2006).

Serologic and virologic studies suggest that bats are the principle reservoir hosts of henipaviruses. Numerous frugivorous bat species of the genus Pteropus (family Pteropodidae) exhibit a high seroprevalence for henipaviruses. In addition, $\mathrm{HeV}$ has been isolated from $P$. poliocephalus and $P$. alecto in Australia (Halpin et al., 1999), NiV has been isolated from $P$. hypomelanu in Malaysia (Chua et al., 2002) and $P$. Iylei in Cambodia (Reynes et al., 2005). Antibodies to henipavirus have also been detected among both frugivorous and insectivorous bats in Thailand (Wacharapluesadee et al., 2005), Indonesia (Sendow et al., 2006), Madagascar (Lehle et al., 2007) and China (Li et al., 2008); however, no virus has been isolated from those tested bat samples.

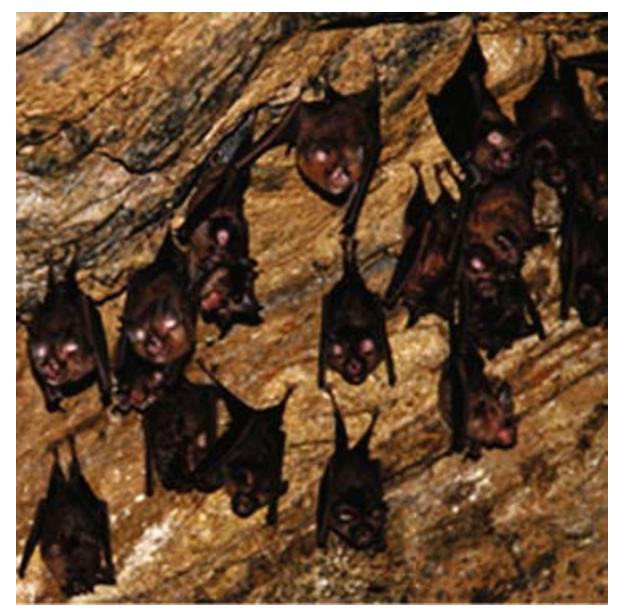

SARS-CoV Bats are recently identified as natural reservoir of SARS-CoV that caused outbreaks of human respiratory disease during 2002-2003 in China and resulted in 8422 cases with 916 deaths in 29 countries and regions (ChanYeung and $\mathrm{Xu}, 2003)$. Antibody and genomic sequences similar to SARS-CoV were discovered in Rhinolophus bat, including $R$. sinicus, $R$. pearsoni, $R$. macrotis and $R$. ferrumequinum and $R$. pusillus (Lau et al., 2005; Poon et al., 2005; Ren et al., 2006). The nucleotide sequences of bat SARS-like CoVs (SL-CoV) have 78\%-92\% identities to SARS-CoV and among themselves, and display great genetic diversity. The phylogenetic analysis indicated that Rhinolophus bat may carry the direct progenitor of human SARS-CoV (Hon et al., 2008).

Filoviruses Marburg virus and Ebola virus, belonging to the family Filoviridae, are two emerging viruses that cause human hemorrhagic fever disease (HF) (Sanchez et al., 2007). The
Marburg virus was recognized during 2-center outbreaks in Marburg, Germany, and Belgrade, former Yugoslavia, in 1967 (Malherbe and Strickland-Cholmley, 1968). The disease was associated with laboratory work using African green monkeys (Cercopithecus aethiops) imported from Uganda. Subsequently, outbreaks and sporadic cases have been reported in Angola, Democratic Republic of the Congo, Kenya, South Africa (in a person traveled to Zimbabwe) and Uganda (http:// www.who.int/csr/disease/marburg/en/). The Ebola virus was first identified in a western equatorial province of Sudan and in a nearby region of Zaire (now the Democratic Republic of the Congo) in 1976 after significant epidemics in Yambuku in northern Democratic Republic of the Congo, and in Nzara in southern Sudan (Emond et al., 1977). Since then, numerous outbreaks have been documented in Democratic Republic of the Congo, Uganda and Sudan (http://www.who.int/csr/ disease/ebola/en/). Four different Ebola virus strains were identified: Zaire, Sudan, Reston and Côte d'Ivoire (Ivory Coast) ebolaviruses, and the former two are associated with HF outbreaks in Africa with high case fatality $(53 \%-90 \%)$ (Sanchez et al., 2007).

Both Zaire and Sudan strains have been detected in bats. Marburg virus was detected in fruit bat Rousettus aegyptiacus in Gabon, Uganda and Democratic Republic of the Congo and in insectivorous bat Rhinolophus eloquens (Swanepoel et al., 2007; Towner et al., 2007, 2009). Zaire Ebola virus was detected in 3 bat species (Epomops franqueti, Hypsignathus monstrosus, and Myonycteris torquata) in Gabon and the Republic of the Congo (Leroy et al., 2005; Biek et al., 2006; Gonzalez et al., 2007; Pourrut et al., 2007, 2009). The available sequence data demonstrated that both Ebola and Marburg virus in bats display genetic diversity.

Melaka virus The Melaka virus, a novel reovirus, was isolated from a 39-year-old male patient in Melaka, Malaysia, who was suffering from high fever and acute respiratory disease upon virus isolation. Two of his family members developed similar symptoms approximately 1 week later and had serological evidence of infection with the same virus. Epidemiological tracing revealed that the family was exposed to a bat in the house approximately 1 week before the onset of the father's clinical symptoms. Genome sequence analysis indicated a close genetic relationship between Melaka virus and Pulau virus, which is a also reovirus isolated in 1999 from fruit bats in Tioman Island, Malaysia (Chua et al., 2007).

\section{PERSISTENT INFECTION AND GENETIC DIVERSITY OF BAT VIRUSES}

In addition to bat borne virus that caused severe human diseases, many other bat viruses that has no evidence to cause animal or human diseases have been discovered in bat populations throughout the world. These viruses were regularly detected in apparently healthy bats and display genetic diversity. 
Other Bat CoVs During the search for the origin of SARS$\mathrm{CoV}$, numerous novel CoVs were detected in large numbers of bat species in China, South and North America, Germany and Africa (Poon et al., 2005; Chu et al., 2006; Ren et al., 2006; Tang et al., 2006; Dominguez et al., 2007; Lau et al., 2007; Muller et al., 2007; Woo et al., 2007; Carrington et al., 2008; Gloza-Rausch et al., 2008; Misra et al., 2009; Pfefferle et al., 2009). The phylogenetic analysis based on the fully sequenced Bat-CoV indicated high genetic diversity that of bat CoVs, which were grouped into CoV group 1, group 2a, 2c and 2d (Ren et al., 2006; Tang et al., 2006; Woo et al., 2007; Lau et al., 2007).

Bat Astroviruses A group of novel astroviruses was found in apparently healthy insectivorous bats, particularly in the genera Miniopterus and Myotis (36\%-100\% and 50\%-70\%, respectively), in Hong Kong (Chu et al., 2008). Similar viruses were detected in a large numbers of bat samples in mainland China (Zhu et al., 2009). The phylogentic analysis revealed a remarkably high genetic diversity of bat astroviruses that form five monophyletic groups clustered in the genus Mamastrovirus within the family Astroviridae. Some bat astroviruses may be phylogenetically related to human astroviruses, implying potential risk of inter-species transmission of Mamastrovirus.

Herpesvirus Herpervirus was initially discovered in little brown bats (Myotis lucifugus) by virus morphology (Tandler, 1996) and later detected in different bat species in The Philippines, Africa and Europe with molecular detection methods (Wibbelt et al., 2007; Molnar et al., 2008; Razafindratsimandresy et al., 2009; Watanabe et al., 2009). The phylogenetic analysis based on obtained partial gene sequences indicated that bat herpesviruses display genetic diversity and form distinct clade within the subfamily Alhaherpesvirinae, Betaherpesvirinae and Gammaherpesvirinae.

Adenovirus A novel adenovirus was isolated by a Japanese scientist during tissue cultures derived from bat spleen from fruit bat $P$. dasymallus yayeyamae. The partial polymerase sequence of this bat adenovirus showed homolog to tree shrew adenovirus 1 (70\% amino acid sequence identity). A Germany group later reported another novel adenovirus in German bats (Sonntag et al., 2009). Recently, our group has also detected genetic diversity adenoviruses in 5 bat species in China (unpublished results), indicating a wide distribution of adenovirus in bat populations.

\section{PERSPECTIVES}

\section{Future screening and preparation of diagnostic methods of bat viruses}

Bats viruses did not attract human attention until recent years when several emerging and reemerging human viruses were associated with bats. However, information about the natural history of most viruses in bats is limited. It is evident that most of the bat viruses have existed in bats for long time. Why did some of them cause severe disease in domestic animals and human in recent years? The invasion of bat habitats and expanding agricultural industry increase the close contact opportunity between bats and human, thus increase the opportunity of virus transmission from bat to domestic animals and human. The molecular detection technology significantly contributes to the discovery of more bat viruses. Considering the diversity of bat species in the world, the currently identified bat viruses may represent only a small part of bat reservoir. Therefore, a wide-ranged screening of bat viruses is required to prepare specific diagnostic methods for preventing future emerging viral diseases in animals and human.

\section{Studies of virus interspecies transmission and evaluation of potential risk of bat viruses}

Viruses usually have narrow host ranges, which restrict them transmitted from one animal to others. However, zoonotic viral diseases consist of more than $70 \%$ among the emerging and remerging viral diseases (Jones et al., 2008). The first step for successful interspecies transmission is that the virus can use the same receptor as found in their original host of other animals for their entering the invading host cells. Some bat borne viruses, such as henipaviruses, have wide host ranges and can easily transmit from bats to animal and human as their cellular receptor ephrin B2 and B3 are highly conserved in different animals. This may explain why Hendrs virus and Nipah virus continually revisiting human and caused disease outbreaks in recent years. Unlike henipaviruses, SARS-CoV, which use the angiotensin converting enzyme 2 (ACE2) as cellular receptor, has a relatively narrow host ranges. The ACE2 protein of different origins are variable at the $\mathrm{N}$-terminal ends that contact directly the receptor binding domain (RBD) of the SARS-CoV spike protein (S). A minor amino acid change in the RBD or ACE2 N-terminal end can abolish the entry of SARS-CoV (Li et al., 2005; Ren et al., 2008). This may partially explain why SARS-CoV completely disappeared when the transmission chain (civet and other small mammals as intermediate hosts) was interrupted. Thus, further studies should focus on the interspecies transmission of bat viruses and evaluate the potential risk of bat viruses to domestic animals and human.

\section{Bat immune response on virus infections}

Most bat viruses known today were discovered in apparently healthy bats. Experimental infection to bat by henipavirus virus and rabies virus also demonstrated that bat shed the virus but did not produce any clinical syndrome as did in other animals and human (Almeida et al., 2005; Hughes et al., 2006; Tjornehoj et al., 2006; Middleton et al., 2007), suggesting that bats may have specific immune system or 
antiviral activity against virus infections. Further knowledge of immune response of bats against viruses might shed light on some key questions of the bat-derived virus infectious diseases. It will be necessary to determine bat genome or transcriptome, to establish bat cell culture-based assays and bat-specific reagents to examine lymphocyte proliferation, antibody and cytokine synthesis, cell-mediated immune responses, and to develop a host of other immunologic functions in bats.

\section{REFERENCES}

Aguirre, L.F., Herrel, A., Van Damme, R., and Matthysen, E. (2003). The implications of food hardness for diet in bats. Functional Ecology 17, 201-212.

Almeida, M.F., Martorelli, L.F., Aires, C.C., Sallum, P.C., Durigon, E.L., and Massad, E. (2005). Experimental rabies infection in haematophagous bats Desmodus rotundus. Epidemiol Infect 133, 523-527.

Badilla, X., Perez-Herra, V., Quiros, L., Morice, A., Jimenez, E., Saenz, E., Salazar, F., Fernandez, R., Orciari, L., Yager, P., et al. (2003). Human rabies: a reemerging disease in Costa Rica? Emerg Infect Dis 9, 721-723.

Badrane, H., and Tordo, N. (2001). Host switching in Lyssavirus history from the Chiroptera to the Carnivora orders. J Virol 75, 8096-8104.

Biek, R., Walsh, P.D., Leroy, E.M., and Real, L.A. (2006). Recent common ancestry of Ebola Zaire virus found in a bat reservoir. PLoS Pathog 2, e90.

Blanton, J.D., Palmer, D., Christian, K.A., and Rupprecht, C.E. (2008). Rabies surveillance in the United States during 2007. J Am Vet Med Assoc 233, 884-897.

Bourhy, H., Kissi, B., and Tordo, N. (1993). Molecular diversity of the Lyssavirus genus. Virology 194, 70-81.

Calisher, C.H., Childs, J.E., Field, H.E., Holmes, K.V., and Schountz, T. (2006). Bats: important reservoir hosts of emerging viruses. Clin Microbiol Rev 19, 531-545.

Carrington, C.V., Foster, J.E., Zhu, H.C., Zhang, J.X., Smith, G.J., Thompson, N., Auguste, A.J., Ramkissoon, V., Adesiyun, A.A., and Guan, Y. (2008). Detection and phylogenetic analysis of group 1 coronaviruses in South American bats. Emerg Infect Dis 14, 1890-1893.

Chadha, M.S., Comer, J.A., Lowe, L., Rota, P.A., Rollin, P.E., Bellini, W.J., Ksiazek, T.G., and Mishra, A. (2006). Nipah virus-associated encephalitis outbreak, Siliguri, India. Emerg Infect Dis 12, 235-240.

Chan-Yeung, M., and Xu, R.H. (2003). SARS: epidemiology. Respirology 8 Suppl, S9-14.

Chu, D.K., Poon, L.L., Chan, K.H., Chen, H., Guan, Y., Yuen, K.Y., and Peiris, J.S. (2006). Coronaviruses in bent-winged bats (Miniopterus spp.). J Gen Virol 87, 2461-2466.

Chu, D.K., Poon, L.L., Guan, Y., and Peiris, J.S. (2008). Novel astroviruses in insectivorous bats. J Virol 82, 9107-9114.

Chua, K.B., Bellini, W.J., Rota, P.A., Harcourt, B.H., Tamin, A., Lam, S.K., Ksiazek, T.G., Rollin, P.E., Zaki, S.R., Shieh, W., et al. (2000). Nipah virus: a recently emergent deadly paramyxovirus. Science 288, 1432-1435.
Chua, K.B., Crameri, G., Hyatt, A., Yu, M., Tompang, M.R., Rosli, J., McEachern, J., Crameri, S., Kumarasamy, V., Eaton, B.T. et al. (2007). A previously unknown reovirus of bat origin is associated with an acute respiratory disease in humans. Proc Natl Acad Sci U S A 104, 11424-11429.

Chua, K.B., Koh, C.L., Hooi, P.S., Wee, K.F., Khong, J.H., Chua, B.H., Chan, Y.P., Lim, M.E., and Lam, S.K. (2002). Isolation of Nipah virus from Malaysian Island flying-foxes. Microbes Infect 4, 145-151.

Dominguez, S.R., O'Shea, T.J., Oko, L.M., and Holmes, K.V. (2007). Detection of group 1 coronaviruses in bats in North America. Emerg Infect Dis 13, 1295-1300.

Eaton, B.T., Broder, C.C., Middleton, D., and Wang, L.F. (2006). Hendra and Nipah viruses: different and dangerous. Nat Rev Microbiol 4, 23-35.

Eaton, B.T., Mackenzie, J.S., and Wang, L.F. (2007). Henipaviruses. In Fields Virology, 5 edn, pp. 1587-1600. Edited by Knipe, D.M., Griffin, D.E., Lamb, R.A., Straus, S.E., Howley, P.M., Martin, M.A. and Roizman, B. Philadelphia, USA: Higher Education Press and Springer-Verlag.

Emond, R.T., Evans, B., Bowen, E.T., and Lloyd, G. (1977). A case of Ebola virus infection. Br Med J 2, 541-544.

Favi, M., de Mattos, C.A., Yung, V., Chala, E., Lopez, L.R., and de Mattos, C.C. (2002). First case of human rabies in chile caused by an insectivorous bat virus variant. Emerg Infect Dis 8, 79-81.

Field, H. (2008). Hendra re-visited. Virologica Sinica 24, 105-109.

Fooks, A.R., McElhinney, L.M., Pounder, D.J., Finnegan, C.J., Mansfield, K., Johnson, N., Brookes, S.M., Parsons, G., White, K., Mclntyre, P.G. et al. (2003). Case report: isolation of a European bat lyssavirus type $2 \mathrm{a}$ from a fatal human case of rabies encephalitis. J Med Virol 71, 281-289.

Gloza-Rausch, F., Ipsen, A., Seebens, A., Gottsche, M., Panning, M., Felix Drexler, J., Petersen, N., Annan, A., Grywna, K., Muller, M., et al. (2008). Detection and prevalence patterns of group I coronaviruses in bats, northern Germany. Emerg Infect Dis 14, 626-631.

Gonzalez, J.P., Pourrut, X., and Leroy, E. (2007). Ebolavirus and other filoviruses. Curr Top Microbiol Immunol 315, 363-387.

Halpin, K., Young, P.L., Field, H., and Mackenzie, J.S. (1999). Newly discovered viruses of flying foxes. Vet Microbiol 68, 83-87.

Hanna, J.N., Carney, I.K., Smith, G.A., Tannenberg, A.E., Deverill, J. E., Botha, J.A., Serafin, I.L., Harrower, B.J., Fitzpatrick, P.F., and Searle, J.W. (2000). Australian bat lyssavirus infection: a second human case, with a long incubation period. Med J Aust 172, 597-599.

Hon, C.C., Lam, T.Y., Shi, Z.L., Drummond, A.J., Yip, C.W., Zeng, F., Lam, P.Y., and Leung, F.C. (2008). Evidence of the recombinant origin of a bat severe acute respiratory syndrome (SARS)-like coronavirus and its implications on the direct ancestor of SARS coronavirus. J Virol 82, 1819-1826.

Hughes, G.J., Kuzmin, I.V., Schmitz, A., Blanton, J., Manangan, J., Murphy, S., and Rupprecht, C.E. (2006). Experimental infection of big brown bats (Eptesicus fuscus) with Eurasian bat lyssaviruses Aravan, Khujand, and Irkut virus. Arch Virol 151, 2021-2035.

Jones, K.E., Patel, N.G., Levy, M.A., Storeygard, A., Balk, D., Gittleman, J.L., and Daszak, P. (2008). Global trends in emerging infectious diseases. Nature 451, 990-993.

Lau, S.K., Woo, P.C., Li, K.S., Huang, Y., Tsoi, H.W., Wong, B.H., Wong, S.S., Leung, S.Y., Chan, K.H., and Yuen, K.Y. (2005). 
Severe acute respiratory syndrome coronavirus-like virus in Chinese horseshoe bats. Proc Natl Acad Sci U S A 102, 14040-14045.

Lau, S.K., Woo, P.C., Li, K.S., Huang, Y., Wang, M., Lam, C.S., Xu, H., Guo, R., Chan, K.H., Zheng, B.J., and Yuen, K.Y. (2007). Complete genome sequence of bat coronavirus HKU2 from Chinese horseshoe bats revealed a much smaller spike gene with a different evolutionary lineage from the rest of the genome. Virology 367 , 428-439.

Lehle, C., Razafitrimo, G., Razainirina, J., Andriaholinirina, N., Goodman, S.M., Faure, C., Georges-Courbot, M.C., Rousset, D., and Reynes, J.M. (2007). Henipavirus and Tioman virus antibodies in pteropodid bats, Madagascar. Emerg Infect Dis 13, 159-161.

Leroy, E.M., Kumulungui, B., Pourrut, X., Rouquet, P., Hassanin, A., Yaba, P., Delicat, A., Paweska, J.T., Gonzalez, J.P., and Swanepoel, R. (2005). Fruit bats as reservoirs of Ebola virus. Nature 438, 575-576.

Li, W., Zhang, C., Sui, J., Kuhn, J.H., Moore, M.J., Luo, S., Wong, S. K., Huang, I.C., Xu, K., Vasilieva, N., et al. (2005). Receptor and viral determinants of SARS-coronavirus adaptation to human ACE2. EMBO J 24, 1634-1643.

Li, Y., Wang, J., Hickey, A.C., Zhang, Y., Wu, Y., Zhang, H., Yuan, J., Han, Z., McEachern, J., Broder, C.C., Wang, L.F., and Shi, Z. (2008). Antibodies to Nipah or Nipah-like viruses in bats, China. Emerg Infect Dis 14, 1974-1976.

Malherbe, H., and Strickland-Cholmley, M. (1968). Human disease from monkeys (Marburg virus). Lancet 1, 1434.

Middleton, D.J., Morrissy, C.J., van der Heide, B.M., Russell, G.M., Braun, M.A., Westbury, H.A., Halpin, K., and Daniels, P.W. (2007). Experimental Nipah virus infection in pteropid bats (Pteropus poliocephalus). J Comp Pathol 136, 266-272.

Misra, V., Dumonceaux, T., Dubois, J., Willis, C., Nadin-Davis, S., Severini, A., Wandeler, A., Lindsay, R., and Artsob, H. (2009). Detection of polyoma and corona viruses in bats of Canada. J Gen Virol 90, 2015-2022.

Molnar, V., Janoska, M., Harrach, B., Glavits, R., Palmai, N., Rigo, D., Sos, E., and Liptovszky, M. (2008). Detection of a novel bat gammaherpesvirus in Hungary. Acta Vet Hung 56, 529-538.

Muller, M.A., Paweska, J.T., Leman, P.A., Drosten, C., Grywna, K., Kemp, A., Braack, L., Sonnenberg, K., Niedrig, M., and Swanepoel, R. (2007). Coronavirus antibodies in African bat species. Emerg Infect Dis 13, 1367-1370.

Murray, K., Selleck, P., Hooper, P., Hyatt, A., Gould, A., Gleeson, L., Westbury, H., Hiley, L., Selvey, L., Rodwell, B. et al. (1995). A morbillivirus that caused fatal disease in horses and humans. Science 268, 94-97.

Nathwani, D., McIntyre, P.G., White, K., Shearer, A.J., Reynolds, N., Walker, D., Orange, G.V., and Fooks, A.R. (2003). Fatal human rabies caused by European bat Lyssavirus type 2a infection in Scotland. Clin Infect Dis 37, 598-601.

Paton, N.I., Leo, Y.S., Zaki, S.R., Auchus, A.P., Lee, K.E., Ling, A.E., Chew, S.K., Ang, B., Rollin, P.E., Umapathi, T., et al. (1999). Outbreak of Nipah-virus infection among abattoir workers in Singapore. Lancet 354, 1253-1256.

Patterson, B.D., Willig, M.R., and Stevens, R.D. (2003). Trophic strategies, niche partitioning, and patterns of ecological organization. In Bat Ecology, pp. 536-579. Edited by IKunz, T.H., and Fenton, M.B.. Chicago: The University of Chicago Press.
Paweska, J.T., Blumberg, L.H., Liebenberg, C., Hewlett, R.H., Grobbelaar, A.A., Leman, P.A., Croft, J.E., Nel, L.H., Nutt, L., and Swanepoel, R. (2006). Fatal human infection with rabies-related Duvenhage virus, South Africa. Emerg Infect Dis 12, 1965-1967.

Pfefferle, S., Oppong, S., Drexler, J.F., Gloza-Rausch, F., Ipsen, A., Seebens, A., Muller, M.A., Annan, A., Vallo, P., Adu-Sarkodie, Y., et al. (2009). Distant relatives of severe acute respiratory syndrome coronavirus and close relatives of human coronavirus 229E in bats, Ghana. Emerg Infect Dis 15, 1377-1384.

Poon, L.L., Chu, D.K., Chan, K.H., Wong, O.K., Ellis, T.M., Leung, Y. H., Lau, S.K., Woo, P.C., Suen, K.Y., Yuen, K.Y., et al. (2005). Identification of a novel coronavirus in bats. J Virol 79, 2001-2009.

Pourrut, X., Delicat, A., Rollin, P.E., Ksiazek, T.G., Gonzalez, J.P., and Leroy, E.M. (2007). Spatial and temporal patterns of Zaire ebolavirus antibody prevalence in the possible reservoir bat species. J Infect Dis 196 Suppl 2, S176-183.

Pourrut, X., Souris, M., Towner, J.S., Rollin, P.E., Nichol, S.T., Gonzalez, J.P., and Leroy, E. (2009). Large serological survey showing cocirculation of Ebola and Marburg viruses in Gabonese bat populations, and a high seroprevalence of both viruses in Rousettus aegyptiacus. BMC Infect Dis 9, 159.

Razafindratsimandresy, R., Jeanmaire, E.M., Counor, D., Vasconcelos, P.F., Sall, A.A., and Reynes, J.M. (2009). Partial molecular characterization of alphaherpesviruses isolated from tropical bats. J Gen Virol 90, 44- 47.

Ren, W., Li, W., Yu, M., Hao, P., Zhang, Y., Zhou, P., Zhang, S., Zhao, G., Zhong, Y., Wang, S., et al. (2006). Full-length genome sequences of two SARS-like coronaviruses in horseshoe bats and genetic variation analysis. J Gen Virol 87, 3355-3359.

Ren, W., Qu, X., Li, W., Han, Z., Yu, M., Zhou, P., Zhang, S.Y., Wang, L.F., Deng, H., and Shi, Z. (2008). Difference in receptor usage between severe acute respiratory syndrome (SARS) coronavirus and SARS-like coronavirus of bat origin. J Virol 82, 1899-1907.

Reynes, J.M., Counor, D., Ong, S., Faure, C., Seng, V., Molia, S., Walston, J., Georges-Courbot, M.C., Deubel, V., and Sarthou, J.L. (2005). Nipah virus in Lyle's flying foxes, Cambodia. Emerg Infect Dis 11, 1042-1047.

Sanchez, A., Geisbert, T.W., and Feldmann, H. (2007). Filoviridae: Marburg and Ebola viruses. In fields virology, pp. 1409-1448. Edited by Knipe, H.P. Philidelphia: Lippincott Williams and Williams.

Sendow, I., Field, H.E., Curran, J., Darminto, Morrissy, C., Meehan, G., Buick, T., and Daniels, P. (2006). Henipavirus in Pteropus vampyrus bats, Indonesia. Emerg Infect Dis 12, 711-712.

Simmons, N.B. (2005). Order Chiroptera. In Mammal species of the world: a taxonomic and geographic reference, 3 edn, pp. 312-529. Edited by Wilson, D.E., and Reeder, D.M. Baltimore: John Hopkins University Press.

Sonntag, M., Muhldorfer, K., Speck, S., Wibbelt, G., and Kurth, A. (2009). New adenovirus in bats, Germany. Emerg Infect Dis 15, 2052-2055.

Sulkin, S., E., and Allen, R. (1974). Virus infction in bats. In Monographs in Virology. Edited by Melnick, J.L.. Houston: S. KargerAG, Basel.

Swanepoel, R., Smit, S.B., Rollin, P.E., Formenty, P., Leman, P.A., Kemp, A., Burt, F.J., Grobbelaar, A.A., Croft, J., Bausch, D.G., et al. (2007). Studies of reservoir hosts for Marburg virus. Emerg Infect Dis $13,1847-1851$. 
Tandler, B. (1996). Cytomegalovirus in the principal submandibular gland of the little brown bat, Myotis lucifugus. J Comp Pathol 114, 1-9.

Tang, X.C., Zhang, J.X., Zhang, S.Y., Wang, P., Fan, X.H., Li, L.F., Li, G., Dong, B.Q., Liu, W., Cheung, C.L., et al. (2006). Prevalence and genetic diversity of coronaviruses in bats from China. J Virol 80, 7481-7490.

Teeling, E.C., Springer, M.S., Madsen, O., Bates, P., O'Brien, S.J., and Murphy, W.J. (2005). A molecular phylogeny for bats illuminates biogeography and the fossil record. Science 307, 580-584.

Tjornehoj, K., Fooks, A.R., Agerholm, J.S., and Ronsholt, L. (2006). Natural and experimental infection of sheep with European bat lyssavirus type-1 of Danish bat origin. J Comp Pathol 134, 190-201.

Towner, J.S., Amman, B.R., Sealy, T.K., Carroll, S.A., Comer, J.A., Kemp, A., Swanepoel, R., Paddock, C.D., Balinandi, S., Khristova, M.L., et al. (2009). Isolation of genetically diverse Marburg viruses from Egyptian fruit bats. PLoS Pathog 5, e1000536.

Towner, J.S., Pourrut, X., Albarino, C.G., Nkogue, C.N., Bird, B.H., Grard, G., Ksiazek, T.G., Gonzalez, J.P., Nichol, S.T., and Leroy, E. M. (2007). Marburg virus infection detected in a common African bat. PLoS One 2, e764.

van Thiel, P.P., van den Hoek, J.A., Eftimov, F., Tepaske, R., Zaaijer,
H.J., Spanjaard, L., de Boer, H.E., van Doornum, G.J., Schutten, M., Osterhaus, A.. et al. (2008). Fatal case of human rabies (Duvenhage virus) from a bat in Kenya: The Netherlands, December 2007. Euro Surveill 13.

Wacharapluesadee, S., Lumlertdacha, B., Boongird, K., Wanghongsa, S., Chanhome, L., Rollin, P., Stockton, P., Rupprecht, C.E., Ksiazek, T.G., and Hemachudha, T. (2005). Bat Nipah virus, Thailand. Emerg Infect Dis 11, 1949-1951.

Watanabe, S., Ueda, N., Iha, K., Masangkay, J.S., Fujii, H., Alviola, P., Mizutani, T., Maeda, K., Yamane, D., Walid, A., et al. (2009). Detection of a new bat gammaherpesvirus in the Philippines. Virus Genes 39, 90-93.

Wibbelt, G., Kurth, A., Yasmum, N., Bannert, M., Nagel, S., Nitsche, A., and Ehlers, B. (2007). Discovery of herpesviruses in bats. J Gen Virol 88, 2651-2655.

Woo, P.C., Wang, M., Lau, S.K., Xu, H., Poon, R.W., Guo, R., Wong, B.H., Gao, K., Tsoi, H.W., Huang, Y., et al. (2007). Comparative analysis of twelve genomes of three novel group $2 c$ and group $2 d$ coronaviruses reveals unique group and subgroup features. J Virol 81, 1574-1585.

Zhu, H.C., Chu, D.K., Liu, W., Dong, B.Q., Zhang, S.Y., Zhang, J.X., Li, L.F., Vijaykrishna, D., Smith, G.J., Chen, H.L., et al. (2009). Detection of diverse astroviruses from bats in China. J Gen Virol 90, 883-887. 